\title{
Decline of the Endangered lion-tailed macaque Macaca silenus in the Western Ghats, India
}

\author{
Honnavalli N. Kumara and Anindya Sinha
}

\begin{abstract}
The Endangered lion-tailed macaque Macaca silenus is endemic to rainforest patches of the Western Ghats mountains in south-western India. Most populations of this primate are severely fragmented and declining and the species is locally extinct in some areas. This study evaluates the status of this macaque in the Talakaveri, Pushpagiri and Sharavathi Valley Wildlife Sanctuaries and adjacent areas in the state of Karnataka. We sighted four, two and three groups, consisting of five, nine and 14 individuals, in these three sanctuaries, respectively. The recently discovered population in the Sirsi-Honnavara area of Karnataka state is possibly the only viable population, with $>750$ individuals, but is confined to unprotected reserve forests with extensive human habitation, agricultural land and livestock reserves. We make recommendations for the long-term conservation of the species, and for the Sirsi-Honnavara population in particular.
\end{abstract}

Keywords Fragmentation, India, Karnataka, lion-tailed macaque, Macaca silenus, rainforest, Western Ghats.

\section{Introduction}

7 he Western Ghats mountain range lies parallel to the 1 western coast of southern India through six states from $8^{\circ}$ to $21^{\circ} \mathrm{N}$ (Pascal, 1988). Although humans have lived in these hills since prehistoric times, organized state-sponsored forestry and non-forestry activities only began c. 200 years ago (Chandran, 1997). Commercial crop plantations, tea and coffee cultivation, construction of hydroelectric dams and power generation brought millions of people to the area and, as a result, wildlife habitats, especially the rainforests, have undergone drastic changes, including extensive fragmentation. However, the Western Ghats still harbours a high diversity of flora and fauna, and is one of eight 'hottest hotspots' of global biodiversity (Myers et al., 2000); it also has the highest human population density of all these eight hotspots (Cincotta et al., 2000). This diversity includes several species of primates, notably the endemic lion-tailed macaque Macaca silenus and the Nilgiri langur Semnopithecus johnii.

Honnavalli N. Kumara (Corresponding author) and Anindya Sinha* National Institute of Advanced Studies, Indian Institute of Science Campus, Bangalore 560012, India. E-mail honnavallik@gmail.com

*Also at: Nature Conservation Foundation, Gokulam Park, Mysore, India.

Received 16 May 2007. Revision requested 26 July 2007.

Accepted 21 September 2007.
The lion-tailed macaque ranges across three southern Indian states: Karnataka, Tamil Nadu and Kerala. Because of its highly selective feeding habits, limited range of occupancy (c. $2,500 \mathrm{~km}^{2}$ ), delayed sexual maturity, long interbirth interval, low turnover and small wild population, it is categorized as Endangered on the IUCN Red List (IUCN, 2008). Habitat loss and fragmentation have severely affected the species (Karanth, 1992; Krishnamurthy \& Kiester, 1998). The current total population size is unknown, although there are some earlier estimates, many extrapolated from short surveys in a few limited areas within the species' range (total population estimates: Green \& Minkowski, 1977; Kurup, 1978; Ali, 1985; Karanth, 1992; Kumar, 1995; Easa et al., 1997; Molur et al., 2003; site-based surveys: Indira Gandhi Wildlife Sanctuary, Singh et al., 2002; Silent Valley National Park, Joseph \& Ramachandran, 1998; Sringeri forest range, Singh et al., 2000; Brahmagiri-Makut and Sirsi-Honnavara areas, Kumara \& Singh, 2004a; Kudremukh National Park, Someshwara Wildlife Sanctuary and the Mookambika Wildlife Sanctuary, Vasudevan et al., 2006).

Karanth (1992), outlining the conservation prospects for the biodiversity of the Western Ghats, emphasized the importance of the lion-tailed macaque as a flagship species for the rapidly declining rainforests of this biodiversity hotspot. Here we report the findings from our recent surveys of the current status of the lion-tailed macaque in three protected areas in Karnataka that have not been surveyed for more than 20 years. We also review the available information on the status of the species across the Western Ghats to identify potentially important populations for its long-term conservation.

\section{Study areas}

The Talakaveri $\left(105 \mathrm{~km}^{2}\right)$, Pushpagiri $\left(102 \mathrm{~km}^{2}\right)$ and Sharavathi Valley $\left(431 \mathrm{~km}^{2}\right)$ Wildlife Sanctuaries and adjacent reserve forests (Fig. 1) have altitude ranges of $63-1,659,60-1,712$ and $300-1,102 \mathrm{~m}$, respectively, a mean annual temperature range of $8-33^{\circ} \mathrm{C}$, and mean annual rainfall of 2,000-3,700 $\mathrm{mm}$. The forests of Talakaveri and Pushpagiri Wildlife Sanctuaries are classified as Medium Altitude Forest Type with Mesua ferrea-Palaquium ellipticum vegetation (Pascal, 1988). To the west lie the Mundrot Reserve Forest and agricultural villages of the state of Kerala, and there are coffee and cardamom plantations to the east. The Sanctuaries are bounded to the north and south by wet evergreen forests and grassy mountain slopes of reserve forests. There are 11 enclosures in these two 


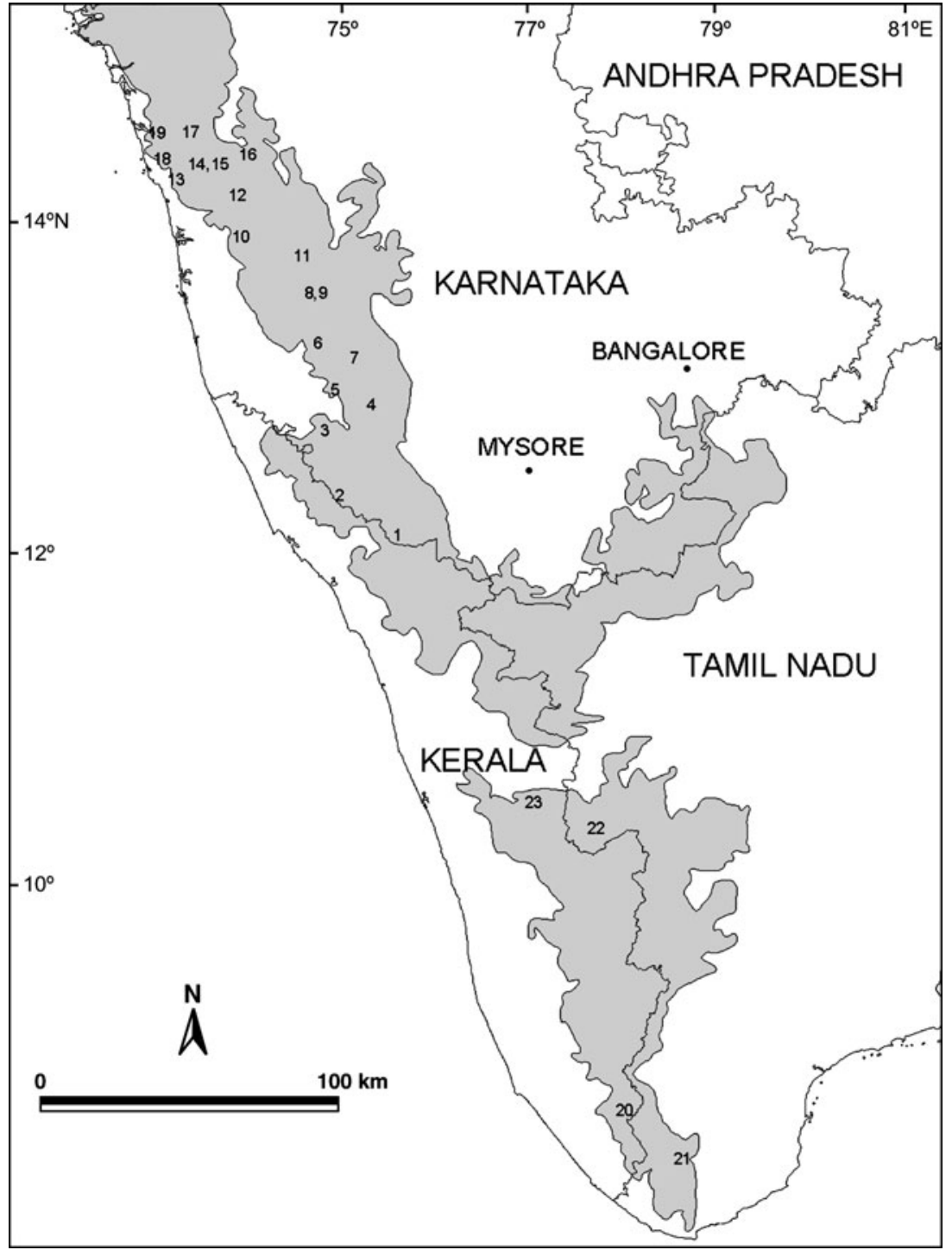

FIG. 1 South-western India, with the Western Ghats mountains (shaded areas) showing the locations of the known lion-tailed macaque populations in the states of Karnataka, Kerala and Tamil Nadu. The names of these numbered sites are given in Tables 2 and 4.
Sanctuaries, including cardamom and coffee plantations, with a human population of c. 2,000 (H.N. Kumara, unpubl. data). The forests of the Sharavathi Valley Wildlife Sanctuary are classified as Low Altitude Rainforest Type with Persea macrantha-Diospyros spp.-Holigarna spp. vegetation (Pascal, 1988). A number of villages ( $>120$, with c. 20,000 people) and extensive commercial crop plantations, including areca nut Areca catechu and rice, lie within the Sanctuary.

\section{Methods}

Lion-tailed macaques occur in low numbers and are restricted to narrow strips of rainforest, c. $20 \mathrm{~km}$ wide, in the Western Ghats mountains. Given their preference for the rainforest canopy, the estimation of macaque density by line transects or distance sampling requires considerable effort, and it is often impossible to use transects because of the rough terrain. We thus employed two different but complementary methods, from January 2005 to August 2006.
Firstly, to evaluate the relative abundance of macaques over the entire study area we selected trails (mean length $3.43 \mathrm{~km}$, range $1.50-6.50 \mathrm{~km}$ ), evenly distributed across all the study sites and including all the representative forest types, and then walked them repeatedly (Table 1). The walks were conducted over $06.30-11.30$ and 15.00-18.30, when the species is active (H.N. Kumara, pers. obs.), at a walking speed of $1-1.5 \mathrm{~km} \mathrm{~h}^{-1}$. We also conducted extensive but opportunistic vehicle surveys throughout the study area to detect as many macaque groups as possible (Table 1). To estimate the actual number and distribution of the macaque groups we then used the total count method (NRC, 1981), as employed for earlier lion-tailed macaque surveys (Joseph \& Ramachandran, 1998; Singh et al., 2000, 2002; Kumara \& Singh, 2004a), with some modifications. Two or three researchers, with two to three trained field assistants, walked in parallel, $100 \mathrm{~m}$ from each other, at least twice, along chosen trails within each study site (Table 1). Given the similarity of the rainforest across the different 
TABLE 1 Sampling effort for lion-tailed macaques in the Talakaveri, Pushpagiri and Sharavathi Valley Wildlife Sanctuaries (sites 3, 4 and 12, respectively, in Fig. 1).

\begin{tabular}{|c|c|c|c|c|}
\hline $\begin{array}{l}\text { Protected } \\
\text { area }\end{array}$ & $\begin{array}{l}\text { No. of } \\
\text { trails }\end{array}$ & $\begin{array}{l}\text { Distance } \\
\text { covered by } \\
\text { repeated trail } \\
\text { walk }(\mathrm{km})\end{array}$ & $\begin{array}{l}\text { Distance } \\
\text { walked for } \\
\text { total } \\
\text { counts }(\mathrm{km})\end{array}$ & $\begin{array}{l}\text { Distance } \\
\text { covered by } \\
\text { vehicle }(\mathrm{km})\end{array}$ \\
\hline Talakaveri & 15 & 302.2 & 95.2 & 480 \\
\hline Pushpagiri & 13 & 184.0 & 82.8 & 426 \\
\hline $\begin{array}{c}\text { Sharavathi } \\
\text { Valley }\end{array}$ & 18 & 186.8 & 125.0 & 800 \\
\hline Total & 46 & 673.0 & 406.2 & 1,706 \\
\hline
\end{tabular}

study sites, we assumed that visibility or detectability differences did not affect our observations or bias the data to any significant extent. We used the typical macaque coo calls, which are usually audible over c. $50 \mathrm{~m}$, to detect the presence of the species. Upon sighting a group its location was noted with a global positioning system and we counted the individuals and determined ages and sex. Additionally, we collected secondary information on macaque sightings from local people, hunters and Forest Department personnel.

All sighting of the species were mapped and compared with the group localities and the species' potential habitat at these sites as described by Karanth (1985). This allowed us to enumerate the likely distribution range of the species within the three Wildlife Sanctuaries.

A total of 84 people $(35,25$ and 24 in the Talakaveri, Pushpagiri and Sharavathi Valley Wildlife Sanctuaries, respectively, of which 18, eight and 19 were active hunters, respectively) were interviewed to evaluate hunting pressures and any perceived economic value of the macaques.

\section{Results}

We located nine groups of lion-tailed macaques: four, two and three in Talakaveri, Pushpagiri and Sharavathi Valley Wildlife Sanctuaries and adjacent reserve forests, respectively (Table 2). As the groups were extremely shy, retreating immediately on approach, it was not possible to collect full demographic data on all of them.

Two of the groups in Talakaveri Wildlife Sanctuary consisted of a single adult male in one and four individuals (two adult males and two adult females) in the other, with neither any females in the former nor any juveniles or infants in the latter. One of the three groups of the SharavathiGersoppa population (Table 2) also consisted of a single adult male although the other two groups were larger, with eight individuals in one (demographic structure unknown) and five (an adult male, two adult females, a subadult male and a juvenile of unknown sex) in the other. The two groups in the Pushpagiri-Subramanya population (Table 2) consisted of four and five individuals respectively, the former with a single adult male, two adult females, a subadult male but no juveniles or infants, and we could not determine the age and sex composition of the latter. Two other groups in the Pushpagiri-Subramanya population were lost when a single adult male was trapped in 2006 (and moved to Mysore Zoo, Karnataka state, in 2007) and the only two individuals of the other group (an adult male and an adult female) were both hunted and killed, again in 2006 (Authors, pers. obs.).

Hunting is one of the most important threats that the lion-tailed macaque faces in the wild. All interviewees in Talakaveri and Pushpagiri Wildlife Sanctuaries reported that the intensity of hunting was high during 1960-1990 but reduced significantly after 1995 because of the low number of macaques. Hunting expeditions by active hunters now extend over a mean of $3.0 \pm$ SD 1.0 days per month, a value believed to be c. $30-40 \%$ of their hunting effort prior to 1995. About $71 \%$ of the interviewed hunters confirmed that hunting still continues in Sharavathi Valley Wildlife Sanctuary (5.8 $\pm \mathrm{SD} 1.2$ days per month). Hunting levels in this Sanctuary are, however, lower than those prior to 1990. Our interviews with local respondents also revealed a widespread belief in the medicinal value of this species because they forage on vegetative materials in the high forest canopy (discussed in detail in Kumara, 2007). This belief appears to have created a commercial value for the species in the villages of Kerala state neighbouring our study areas (Kumara \& Singh, 2004b; Kumara, 2007).

\section{Discussion}

\section{Status in Karnataka state}

Karanth (1985) estimated the minimum area required by an average group of macaques in Karnataka and, following a questionnaire survey, reported the existence of 123 groups, some of which still persist. He reported 10 groups each in Talakaveri Wildlife Sanctuary and Pushpagiri Wildlife Sanctuary and adjacent areas, and nine groups in Sharavathi Valley Wildlife Sanctuary and adjacent areas. Our survey shows an overall $69 \%$ decline in the groups in the same areas (Table 2). The species is similarly threatened in other protected areas of the state. Kumara \& Singh (2004a), for example, reported only a single group in BrahmagiriMakut; this population has declined by $>90 \%$ from that reported by Karanth (1985) and now consists of only five individuals. In contrast, however, Karanth reported only six groups in Sirsi-Honnavara but Kumara \& Singh (2004a) later reported 32 groups there. Karanth reported nine groups in the Kerekatte (formerly Sringeri) Forest Range in the Kudremukh National Park and this was confirmed in two later surveys (Singh et al., 2000; Vasudevan et al., 2006). Vasudevan et al. (2006) reported another three groups in Kudremukh National Park and Someshwara and Mookambika Wildlife Sanctuaries, from where Karanth (1985) had reported 
TABLE 2 Number of lion-tailed macaque groups in protected areas and adjacent ranges in Karnataka state (Fig. 1), as estimated by Karanth (1985) and in more recent studies.

\begin{tabular}{|c|c|c|c|c|c|}
\hline \multirow[b]{2}{*}{$\begin{array}{l}\text { Map } \\
\text { location }^{1}\end{array}$} & \multirow[b]{2}{*}{ Area $^{2}$} & \multirow[b]{2}{*}{ Ranges } & \multirow[b]{2}{*}{$\begin{array}{l}\text { No. of groups } \\
\text { (Karanth, 1985) }\end{array}$} & \multicolumn{2}{|c|}{ Recent surveys } \\
\hline & & & & $\begin{array}{l}\text { No. of } \\
\text { groups }\end{array}$ & Source \\
\hline 1 & Brahmagiri WS & ${\text { Srimangala, } \text { Makut }^{3}}^{3}$ & 4 & 0 & Kumara \& Singh (2004a) \\
\hline 2 & Makut RF & Makut $^{3}$ & 6 & 1 & Kumara \& Singh (2004a) \\
\hline 3 & Talakaveri WS & Bhagamandala & 10 & 4 & This study \\
\hline 4 & Pushpagiri WS & Sampaja $^{4}$ & 1 & 0 & This study \\
\hline 5 & Subramanya RF & Subramanya ${ }^{4}$ & 6 & 1 & This study \\
\hline 6 & Yesalur RF & Yesalur $^{4}$ & 1 & 0 & This study \\
\hline 7 & Sakaleshpur RF & Sakaleshpur ${ }^{4}$ & 2 & 1 & This study \\
\hline 8 & Kudremukh NP & Kerekatte & 9 & 10 & Singh et al. (2000) \\
\hline 9 & Kudremukh NP & & 44 & 6 & Vasudevan et al. (2006) \\
\hline 10 & Mookambika WS & & 12 & 1 & Vasudevan et al. (2006) \\
\hline 11 & Someshwara WS & & 6 & 2 & Vasudevan et al. (2006) \\
\hline 12 & Sharavathi Valley WS & Kogar $^{5}$ & 5 & 2 & This study \\
\hline 13 & Bhatkal RF & Bhatkal $^{5}$ & 2 & 1 & This study \\
\hline 14 & Gersoppa RF & Gersoppa $1^{5}$ & 2 & 0 & This study \\
\hline 15 & Gersoppa RF & Gersoppa $2^{6}$ & 2 & 10 & Kumara \& Singh (2004a) \\
\hline 16 & Siddapur RF & Siddapur ${ }^{6}$ & 2 & 2 & Kumara \& Singh (2004a) \\
\hline 17 & Kyadagi RF & Kyadagi $^{6}$ & 1 & 17 & Kumara \& Singh (2004a) \\
\hline 18 & Honnavara RF & Honnavara $^{6}$ & 0 & 3 & Kumara \& Singh (2004a) \\
\hline 19 & Kumta RF & Kumta & 1 & 0 & Kumara \& Singh (2004a) \\
\hline Total & & & 116 & 61 & \\
\hline
\end{tabular}

${ }^{1}$ Depicted in Fig. 1

${ }^{2}$ WS, Wildlife Sanctuary; RF, Reserve Forest; NP, National Park

${ }^{3}$ Brahmagiri-Makut population

${ }^{4}$ Pushpagiri-Subramanya population (referred to as Pushpagiri Wildlife Sanctuary in text)

${ }^{5}$ Sharavathi-Gersoppa population (referred to as Sharavathi Valley Wildlife Sanctuary in text)

${ }^{6}$ Sirsi-Honnavara population

62 groups, but they suspect the occurrence of more groups in this region. In summary, lion-tailed macaques occur in 31 Forest Ranges (each of which is c. $100 \mathrm{~km}^{2}$ in size in the Western Ghats) in Karnataka. Ground surveys with robust methods have been conducted in 17 of these ranges (Singh et al., 2000; Kumara \& Singh 2004a; this study) and 14 remain unexplored.

Our interviews with local people revealed that severe hunting pressure on the lion-tailed macaque has probably lead to its decline in Karnataka. Local extinction of the species due to hunting has been reported in other parts of the species' range (Kumara \& Singh, 2004a,b) and if hunting is not controlled local extinction is inevitable in other areas. In addition to hunting, habitat loss and fragmentation have resulted in population fragmentation and isolation of macaque groups over much of its range (Kumar et al., 1995; Umapathy \& Kumar, 2000; Singh et al., 2002). Habitat loss, habitat fragmentation and hunting have collectively led to an increase in the number of macaque subpopulations, increase in inter-subpopulation distances, skewed sex ratios, low immature to adult ratios and reduced male migration, all of which may result in inviable populations. An example of this is the skewed demographic structure of the seven groups evaluated in the Talakaveri, Pushpagiri and Sharavathi Valley Wildlife Sanctuaries and adjacent areas in our study, with a total of 10 adult and subadult males, seven adult females and only a single surviving juvenile, i.e. a population seemingly in severe decline. In addition, repeatedly observed solitary adult males could represent severely truncated populations, although they could also be males transferring between groups (Kumar et al., 2001). Long-term demographic studies of these groups are required.

\section{Status across the Western Ghats}

The status of the lion-tailed macaque over its entire range in the Western Ghats or specifically in Karnataka state, as estimated by various studies, is summarized in Table 3. No estimates are available separately for Tamil Nadu state. In two theoretical population assessments the lion-tailed macaque population across the entire Western Ghats was estimated at 3,500-4,000 (Kumar, 1995) and 3,500 individuals (Molur et al., 2003). The species appears to consist of 49 fragmented subpopulations in eight locations (Molur et al., 2003). 
TABLE 3 Number of groups and total number of individuals of lion-tailed macaques in the Western Ghats overall, and separately in Kerala and Karnataka states, estimated in various studies.

\begin{tabular}{|c|c|c|c|}
\hline Area & $\begin{array}{l}\text { No. } \\
\text { of } \\
\text { groups }\end{array}$ & $\begin{array}{l}\text { Total } \\
\text { no. of } \\
\text { individuals }\end{array}$ & Source \\
\hline Western Ghats & & 600 & $\begin{array}{l}\text { Green \& Minkowski } \\
\text { (1977) }\end{array}$ \\
\hline Western Ghats & 55 & 825 & Kurup (1978) \\
\hline Western Ghats & 61 & 915 & Ali (1985) \\
\hline Western Ghats & & $3,500-4,000$ & Kumar (1995) \\
\hline Western Ghats & & 3,500 & Molur et al. (2003) \\
\hline Kerala state & & $635-735$ & Joseph (1985) \\
\hline Karnataka state & 200 & 3,000 & Karanth (1985) \\
\hline Karnataka state & & $1,000-2,000$ & Karanth (1992) \\
\hline \multirow[t]{2}{*}{ Kerala state } & & $475-594$ & $\begin{array}{l}\text { Government of Kerala } \\
\text { (1993) }\end{array}$ \\
\hline & & 1,216 & Easa et al. (1997) \\
\hline
\end{tabular}

Our surveys and a review of the literature suggest that contiguous populations occur only in seven areas in the Western Ghats (Table 4). The Kalakad-Mundanthurai Tiger Reserve in southern Tamil Nadu, for example, has c. $1,000 \mathrm{~km}^{2}$ of rainforest remaining and is believed to harbour a relatively large population (Molur et al., 2003).

\section{The last viable population?}

The large, recently discovered population of c. 32 groups of the species in the unprotected Reserve Forests of SirsiHonnavara in southern Karnataka possibly represents the last viable, contiguous population of the macaque in its natural habitat (Kumara \& Singh, 2004a; Kumara, 2005). The nine evaluated groups of this population appear to represent a healthy population of 17 adult males, 71 adult females, 70 subadults and juveniles, and 34 infants (Kumara \& Singh, 2004a).

\section{Conservation}

Despite the existence of protected areas the lion-tailed macaque is generally in decline. Wildlife protection and management are not effective, possibly because of insufficient staff, and little monitoring is taking place. The information that does exist is rarely included in Forest Division management plans. We believe that the development of protected areas with proper guidelines and strict law enforcement continues to be a viable way to protect severely threatened species such as the lion-tailed macaque. Accordingly, we recommend that the forests of Sirsi-Honnavara be declared a protected area, with the establishment of a Biosphere Reserve or a Wildlife Sanctuary, to ensure the survival of what is possibly the largest, most viable, population of the lion-tailed macaque remaining in the wild.

All the protected areas with lion-tailed macaque populations need to be identified, species-specific management plans developed, and these plans incorporated into the overall management plans of the respective areas. Annual censuses of all macaque groups and individuals should be mandatory, to monitor population trends and to evaluate the effectiveness of the protection strategies being implemented. As hunting is the major threat to the species' survival, particularly in Karnataka, a legislative framework needs to be imposed and adequate reserve staff employed.

We therefore propose that a conservation strategy for the long-term survival of the lion-tailed macaque over its entire range needs to include: (1) Extensive surveys of lesser-known populations using robust, standardized field methods. (2) Long-term studies of the demography, ecology and behaviour of macaque groups in selected populations. (3) Assessment of the threats to the populations and their habitat, including illegal encroachment into the forest for forestry product collection, firewood and timber extraction, livestock grazing and illegal hunting. (4) Studies of

TABLE 4 Major lion-tailed macaque populations in the Western Ghats.

\begin{tabular}{|c|c|c|c|}
\hline Forest area (location in Fig. 1) & No. of groups & Comments & Source \\
\hline $\begin{array}{l}\text { Kalakad-Mundanthurai Tiger } \\
\text { Reserve, Tamil Nadu state (21) }\end{array}$ & Unknown & $\begin{array}{l}\text { Large rainforest tracts of c. } 1,000 \mathrm{~km}^{2} \text {, } \\
\text { expected to have a good population } \\
\text { although no data available }\end{array}$ & Molur et al. (2003) \\
\hline $\begin{array}{l}\text { Indira Gandhi Wildlife Sanctuary, } \\
\text { Tamil Nadu state }(22)\end{array}$ & 32 & $\begin{array}{l}\text { Fragmented population, present in both } \\
\text { protected \& non-protected forests }\end{array}$ & Singh et al. (2002) \\
\hline $\begin{array}{l}\text { Shendurney-Kulathupuzha- } \\
\text { Peppara-Neyyar, Kerala state (20) }\end{array}$ & $20-25$ & $\begin{array}{l}\text { One of the largest populations in } \\
\text { continuous forest tracts }\end{array}$ & Easa et al. (1997) \\
\hline $\begin{array}{l}\text { Silent Valley National Park, } \\
\text { Kerala state }(23)\end{array}$ & 14 & Possibly a viable population & $\begin{array}{l}\text { Joseph \& } \\
\text { Ramachandran (1998) }\end{array}$ \\
\hline $\begin{array}{l}\text { Kudremukha-Someshwara, } \\
\text { Karnataka state }\end{array}$ & $6+$ & $\begin{array}{l}\text { Large continuous forest; no proper } \\
\text { survey but there may be more groups }\end{array}$ & Vasudevan et al. (2006) \\
\hline $\begin{array}{l}\text { Mookambika-Sharavathi- } \\
\text { Gersoppa, Karnataka state }\end{array}$ & $3+$ & $\begin{array}{l}\text { Most of the groups have disappeared } \\
\text { due to hunting (Table 2) }\end{array}$ & $\begin{array}{l}\text { Vasudevan et al. (2006); } \\
\text { this study }\end{array}$ \\
\hline Sirsi-Honnavara, Karnataka state & 32 & $\begin{array}{l}\text { Non-protected, continuous forest; } \\
\text { a viable population }\end{array}$ & $\begin{array}{l}\text { Kumara \& Singh (2004b); } \\
\text { Kumara (2005) }\end{array}$ \\
\hline
\end{tabular}


the socio-economic status and lifestyles of the local people in the areas where the macaques occur and the nature of their interactions with the lion-tailed macaque.

Our specific recommendations for the conservation of the Sirsi-Honnavara subpopulation, in addition to those listed above, include: (1) Mapping of the distribution of the population, the administrative forest boundaries including villages and croplands, and the boundary of the proposed protected area. (2) A feasibility study for the declaration of the forested areas of Sirsi-Honnavara as a protected area or to assess the possibility of joining this region to the neighbouring Sharavathi Valley Wildlife Sanctuary; the latter would require an evaluation of the existing threats to the Sanctuary. (3) Preparation of a conservation action plan on the basis of these studies and after negotiations with the concerned management authorities. We have recently begun to map the range of this population and to investigate the demography and foraging ecology of selected troops. A conservation action plan has also been developed for this subpopulation and submitted to the forest administration and state government for implementation.

\section{Acknowledgements}

We are grateful to the Chief Wildlife Warden and the officials of the Karnataka Forest Department, particularly A.K. Varma, Anur Reddy, Vijay Mohanraj, G.A.N. Karkikar, M.M. Jaya, N. Ravindra Kumar, D.S. Dayananda, H.S. Jayakumar and Suresh Babu, for research permissions and field assistance. HNK received financial support from the Rufford Maurice Laing Foundation, London, UK. We acknowledge the help and support of M. Mohan Kumar, B. Somashekar and Shanthala Kumar both in the field and during data analysis. We express our gratitude to Josh Cole, Jane Raymonds, Mewa Singh, Werner Kaumanns, Ajith Kumar, Surendra Mal Mohnot, Thomas T. Struhsaker, H.S. Sushma, M. Ananda Kumar, many volunteers and our field assistants.

\section{References}

Ali, R. (1985) An overview of the status and distribution of the lion-tailed macaque. In The Lion-tailed Macaque: Status and Conservation (ed. P.G. Heltne), pp. 13-25. Alan R. Liss, New York, USA.

Chandran, M.D.S. (1997) On the ecological history of the Western Ghats. Current Science, 73, 146-155.

Cincotta, R.P., Wisnewsin, J. \& Engelman, R. (2000) Human population in the biodiversity hotspots. Nature, 404, 990-992.

EASA, P.S., Asari, P.K.S. \& BASHA, S.C. (1997) Status and distribution of the endangered lion-tailed macaque Macaca silenus in Kerala, India. Biological Conservation, 80, 33-37.

Government of Kerala (1993) Forest Statistics. Department of Forests, Government of Kerala, Thiruvananthapuram, India.

Green, S.M. \& Minkowski, K. (1977) The lion-tailed macaque and its south Indian rainforest habitat. In Primate Conservation (eds G.H. Bourne \& H.S.H. Rainier), pp. 289-337. Academic Press, New York, USA.

IUCN (2008) 2008 Red List of Threatened Species. IUCN, Gland, Switzerland. Http://www.iucnredlist.org [accessed 1 April 2008].

Joseph, G.K. \& Ramachandran, K.K. (1998) Recent population trends and management of lion-tailed macaque (Macaca silenus) in Silent Valley National Park, Kerala, India. Indian Forester, $124,833-840$.

Joseph, K.J. (1985) Macaca silenus, the lion-tailed macaque: its status and habitat management in Kerala. In The Lion-tailed Macaque: Status and Conservation (ed. P.G. Heltne), pp. 27-39. Alan R. Liss, New York, USA.

Karanth, K.U. (1985) Ecological status of the lion-tailed macaque and its rainforest habitats in Karnataka, India. Primate Conservation, 6, 73-84.

Karanth, K.U. (1992) Conservation prospects for lion-tailed macaques in Karnataka, India. Zoo Biology, 11, 33-41.

Krishnamurthy, R.S. \& Kiester, A.R. (1998) Analysis of liontailed macaque habitat fragmentation using satellite imagery. Current Science, 75, 283-291.

Kumar, A. (1995) The life history, ecology, distribution and conservation problems in the wild. In The Lion-tailed Macaque: Population and Habitat Viability Assessment Workshop (eds A. Kumar, S. Molur \& S. Walker), pp. 1-11. Zoo Outreach Organization, Coimbatore, India.

Kumar, A., Umapathy, G. \& Prabhakar, A. (1995) A study of the management and conservation of small mammals in fragmented rain forests in the Western Ghats, south India: a preliminary report. Primate Conservation, 16, 53-58.

Kumar, M.A., Singh, M., Kumara, H.N., Sharma, A.K. \& BERTSCH, C. (2001) Male migration in lion-tailed macaques. Primate Report, 58, 5-17.

Kumara, H.N. (2005) An ecological assessment of mammals in nonsanctuary areas of Karnataka. PhD thesis, University of Mysore, Mysore, India.

Kumara, H.N. (2007) Impact of Local Hunting on Abundance of Large Mammals in Three Protected Areas of the Western Ghats, Karnataka. Technical Report, submitted to Rufford Maurice Laing Foundation, London, UK. National Institute of Advanced Studies, Bangalore, India.

Kumara, H.N. \& Singh, M. (2004a) Distribution of primates and conservation of Macaca silenus in rainforests of the Western Ghats, Karnataka, India. International Journal of Primatology, 25, 1001-1018.

Kumara, H.N. \& SingH, M. (2004b) The influence of differing hunting practices on the relative abundance of mammals in two rainforest areas of the Western Ghats, India. Oryx, 38, 321-327.

KURUP, G.U. (1978) Distribution, habitat and status survey of the lion-tailed macaque, Macaca silenus. Journal of the Bombay Natural History Society, 75, 321-340.

Molur, S., Brandon-Jones, D., Dittus, W., Eudey, A., Kumar, A., SingH, M. et al. (2003) Status of South Asian Primates: Conservation Assessment and Management Plan (C.A.M.P.) Workshop Report, 2003. Zoo Outreach Organization/CBSG-South Asia, Coimbatore, India.

Myers, N., Mittermeier, R.A., Mittermeier, C.G., Da Fonseca, G.A.B. \& KenT, J. (2000) Biodiversity hotspots for conservation priorities. Nature, 403, 853-858.

NRC (National Research Council) (1981) Techniques for the Study of Primate Population Ecology. National Academy Press, Washington, DC, USA.

PASCAL, J.P. (1988) Wet Evergreen Forests of the Western Ghats of India. Institut Français de Pondicherry, Pondicherry, India. 
Singh, M., Kumara, H.N., Kumar, M.A., Sharma, A.K. \& DeFAlCo, K. (2000) Status and conservation of lion-tailed macaque and other arboreal mammals in tropical rainforests of Sringeri Forest Range, Western Ghats, Karnataka, India. Primate Report, 58, 5-16.

Singh, M., Singh, M., Kumar, M.A., Kumara, H.N., Sharma, A.K. \& KaUmanns, W. (2002) Distribution, population structure and conservation of lion-tailed macaque (Macaca silenus) in Anaimalai Hills, Western Ghats, India. American Journal of Primatology, 57, 91-102.

Umapathy, G. \& Kumar, A. (2000) The occurrence of arboreal mammals in rainforest fragments in the Anamalai Hills, south India. Biological Conservation, 92, 311-319.

Vasudevan, K., Singh, M., Singh, V.R., Chaitra, M.S., NaniWadekar, R.S., Deepak, V. \& Swapna, N. (2006) Survey of
Biological Diversity in Kudremukh Forest Complex, Karnataka. Final Survey Report of Kudremukh Wildlife Division. Karnataka Forest Department, Karkala, India.

\section{Biographical sketches}

Honnavalli N. KUmara is particularly interested in the behavioural ecology of primates but works for the conservation of all mammalian fauna over a range of habitats within and outside protected areas in peninsular India. ANindya Sinha studies behavioural ecology and cognitive psychology of primates, animal population and molecular genetics, evolutionary biology, conservation science and the philosophy of biology. He is also interested in biology education and the popularization of science in India. 